\title{
TEKNIK PENYUSUNAN INSTRUMEN PENILAIAN HIGHER ORDER THINKING SKILL (HOTS) DALAM PEMBELAJARAN SEJARAH
}

\author{
Ulfah Nury Batubara ${ }^{1}$, Ajat Sudrajat ${ }^{2}$ \\ 1,2Program Pascasarjana Universitas Negeri Yogyakarta \\ 1,2Jalan Colombo No.1, Karang Malang, Daerah Istimewa Yogyakarta 5528 \\ Email : ulfahnury@gmail.com¹, ajat@uny.ac.id 2
}

\begin{abstract}
Abstrak:
Instrumen penilaian HOTS sangat penting mengingat standar yang harus dicapai dalam kurikulum 2013. Tujuan penelitian ini adalah mengkaji teknik penyusunan instrumen untuk mengukur kemampuan berpikir tingkat tinggi yang terdiri dari menganalisis (C-4), mengevaluasi (C-5), dan mengkreasikan (C-6). Metode penelitian yang digunakan adalah metode deskriptif, yaitu menggambarkan masalah untuk memperoleh jawaban dengan berbagai kajian pustaka. Metode penelitian deskriptif berusaha mendeskripsikan suatu gejala, peristiwa atau kejadian yang terjadi saat sekarang. Teknik pengumpulan data penelitian berupa data-data kepustakaan yang telah dipilih, dicari, disajikan dan dianalisis berupa teknik penyusunan instrumen penilaian HOTS khususnya dalam pembelajaran sejarah. Hasil penelitian menunjukkan bahwa teknik penyusunan instrumen penilaian berbasis HOTS dalam pembelajaran sejarah terdiri dari (1) menganalisa KD; (2) mengembangkan kisi-kisi; (3) memilih stimulus yang menarik dan konstektual; (4) menulis butir pertanyaan sesuai dengan kisi-kisi soal; (5) menentukan kunci jawaban/pedoman penskoran; (6) melakukan analisis kualitatif; dan (7) melakukan analisis kuantitatif.
\end{abstract}

\begin{abstract}
:
HOTS assessment is very important considering the standard that must be achieved in the 2013 curriculum. The purpose of this research was to study the instrument drafting techniques to asses the students' high-level thinking skills which consisted of analyzing (C-4), evaluating (C-5), and creating (C-6). The research method used was descriptive method which described the problems to obtain answers from various literature studies. Descriptive research tried to describe phenomenon that occured in that time. Data collection were through study literatures of drafting instruments of HOTS assessment which had been choosen, searched, presented, and analyzed especially in History learning. The results of this study showed that instrument drafting techniques base on HOTS assesment in learning History consisted of (1) analysing base competency, (2) developing the main points, (3) choosing the interested and contextual stimulus, (4) making questions base on the main points, (5) deciding the answer form/score form, (6) doing qualitative analysis, and (7) doing quantitative analysis.
\end{abstract}

Kata kunci:

Instrumen, Penilaian, HOTS

How to Cite: Batubara, U. N. \& Sudrajat, A. (2019). Teknik Penyusunan Instrumen Penilaian Higher Order Thinking Skill (HOTS) dalam Pembelajaran Sejarah. Lentera Pendidikan : Jurnal Ilmu Tarbiyah dan Keguruan, 22(2), 335-344. 


\section{PENDAHULUAN}

Peraturan Pemerintah Indonesia melalui kementerian pendidikan dasar dan menengah menetapkan sejarah sebagai sebuah mata pelajaran yang penting dalam kurikulum 2013, khususnya bagi pendidikan Sekolah Menengah Atas (SMA). Ketetapan tersebut dijelaskan dalam Permendiknas No. 59 tahun 2014 pasal 5 ayat 1 bahwa mata pelajaran sejarah termasuk dalam kelompok A, yakni kelompok pelajaran dengan kategori wajib pada semua jenjang kelas di SMA. Selain itu, pelajaran sejarah juga masuk pada kelompok C yakni kelompok mata pelajaran peminatan bagi peserta didik yang mengambil Ilmu Pengetahuan Sosial (IPS). Posisi mata pelajaran sejarah dalam kurikulum 2013 memiliki posisi yang terhormat jika dibandingkan dengan kurikulum-kurikulum sebelumnya.

Mata pelajaran sejarah di SMA mengkaji berbagai peristiwa sejarah khususnya di Indonesia yang bertujuan untuk membangun memori kolektif agar peserta didik mengenal jati diri bangsanya. Lebih lanjut, tujuan pembelajaran sejarah adalah sebagai landasan dalam membangun kehidupan berbangsa dan bernegara pada masa kini maupun masa yang akan datang (Zulkarnain, 2017: 40). Sementara itu, mata pelajaran sejarah ditinjau dari segi keilmuan bertujuan untuk memberikan latihan mental dalam membandingkan, membedakan, menguji data, mengambil kesimpulan, mempertimbangkan bukti, menghubungkan sebab-akibat dan memilah kebenaran dari kisah-kisah yang bertentangan (Kochhar, 2008: 55).

Jika seorang guru ingin mengetahui sejauh mana ketercapaian peserta didik dalam menguasai tujuan pembelajaran sejarah, maka harus dilakukan penilaian. Standar penilaian pada kurikulum 2013 dilakukan dengan mengadaptasi modelmodel penilaian berstandar internasional. Salah satu model penilaian berstandar internasional tersebut adalah HOTS (Higher Order Thinking Skill) untuk menilai apakah peserta didik sudah memiliki kemampuan berpikir tingkat tinggi, seperti menganalisis, mengevaluasi, dan mengkreasikan. Mainali (2012: 6) menyatakan bahwa HOTS merupakan kemampuan berpikir kritis, logis, reflektif, metakognitif, dan kreatif, dengan kata lain HOTS merupakan proses berpikir yang melibatkan pengolahan informasi secara kritis dan kreatif dalam menghadapi situasi atau menyelesaikan permasalahan tertentu.

Penelitian tentang instrumen penilaian HOTS sudah mulai banyak dilakukan. Penelitian tersebut, diantaranya Pi'i yang mengembangkan penilaian berpikir tingkat tinggi pada pembelajaran sejarah di SMAN 1 Turen Kabupaten Malang. Hasil penelitian menyatakan dari $27 \mathrm{KD}$ pengetahuan untuk mata pelajaran sejarah Indonesia (wajib) terdapat $3 \mathrm{KD}$ pada level berpikir tingkat rendah, dan selebihnya 24 KD pada level berpikir tingkat tinggi. Sementara untuk mata pelajaran sejarah (peminatan IPS) dari $29 \mathrm{KD}$ pengetahuan hanya terdapat $1 \mathrm{KD}$ pada level berpikir tingkat rendah dan selebihnya $28 \mathrm{KD}$ pada level berpikir tingkat tinggi. Hal ini membuktikan bahwa, walaupun mata pelajaran sejarah diorientasikan untuk pembentukan sikap dan pendidikan karakter, tetapi tidak mengesampingkan sejarah sebagai ilmu (Pi'i, 2016). Studi lain dilakukan oleh Umi \& Eka (2015) mengenai 
instrumen penilaian HOTS berbasis kurikulum 2013 terhadap sikap disiplin khususnya pada mata pelajaran fisika. Hasil penelitian menunjukkan terdapat pengaruh positif HOTS dengan sikap disiplin peserta didik. Peserta didik yang memiliki pola keterampilan berpikir HOTS juga mencapai skor penguasaan konsep fisika yang tinggi.

Penelitian ini berbeda dengan penelitian-penelitian yang telah dilakukan sebelumnya. Dalam penelitian Pi'i (2016), banyak menjabarkan Kompetensi Dasar (KD) pada mata pelajaran sejarah yang memuat level kognitif HOTS. Sementara penelitian Umi \& Eka (2015) yakni menerapkan penilaian HOTS pada aspek afektif (sikap disiplin) terutama pada mata pelajaran fisika. Perbedaan penelitian ini dengan penelitian sebelumnya terletak pada langkah-langkah dalam membuat penilaian berbasis HOTS. Penelitian ini menjabarkan bagaimana membuat soal atau tes yang berbentuk HOTS agar bisa menjadi panduan dan pedoman bagi guru khususnya pada mata pelajaran sejarah.

Instrumen penilaian berbasis HOTS pada mata pelajaran sejarah menjadi penting sebab standar penilaian kurikulum 2013 menyebabkan guru-guru sejarah mengalami kesulitan untuk mengembangkan instrumen penilaian berbasis HOTS, sehingga peserta didik belum dilatih untuk berpikir kritis dan analitis. Hasil penelitian Anggara (2015) mengungkapkan bahwa beberapa kesulitan yang dialami oleh guru sejarah adalah pengembangan instrumen penilaian berisi kisi-kisi soal dan kunci jawaban. Kesulitan tersebut disebabkan karena guru tidak menentukan kriteria yang pasti pada saat melakukan penilaian, sehingga penilaian yang dilakukan oleh guru kebanyakan hanya melalui ingatan semata dan bukan hasil akumulasi nilai yang terkumpul. Penelitian lain yang dilakukan oleh Mardapi (1999: 45) juga mengungkapkan bahwa masih banyak guru dalam membuat soal tes tidak berpedoman pada kisi-kisi tes, tetapi cenderung hanya menggunakan soal pada buku-buku yang beredar di pasaran.

Kecenderungan guru dalam membuat soal tidak berpedoman pada kisi-kisi tes, menyebabkan peserta didik kurang terlatih dalam berpikir tingkat tinggi atau yang dikenal dengan Higher Order Thinking Skill (HOTS). Lebih lanjut Widana (2017: 1) menyimpulkan bahwa kemampuan peserta didik di Indonesia sangat rendah. Kemampuan tersebut terlihat dalam memahami informasi yang kompleks, memahami teori, analisis, kemampuan melakukan investigasi, kemampuan dalam pemakaian alat, prosedur, dan pemecahan masalah. Hasil studi internasional PISA (Programme for International Student Assessment) yang meliputi kegiatan literasi membaca (reading literacy), literasi matematika (mathematical literacy), dan literasi sains (scientific literacy) juga mengungkapkan bahwa peserta didik Indonesia prestasinya sangat rendah dalam: (1) memahami informasi yang kompleks; (2) teori, analisis, dan pemecahan masalah; (3) pemakaian alat, prosedur dan pemecahan masalah; serta (4) melakukan investigasi (Pi'i, 2016: 198).

Sejak tahun 2018 pemerintah telah memasukkan soal-soal bertipe HOTS sebanyak $10 \%$ dari soal-soal yang diujikan pada pelaksanaan Ujian Nasional (UN) 
tahun 2018. Sementara tahun 2019, pemerintah rencananya akan memasukkan soalsoal bertipe HOTS sebanyak $15 \%-20 \%$. Hal ini membuktikan porsi soal yang bertipe HOTS akan semakin meningkat dibanding tahun sebelumnya. Penambahan kuota soal dengan tipe HOTS dimaksudkan agar pembelajaran lebih bermakna dan berkualitas. Melalui tuntutan tersebut, pendidikan di Indonesia tidak kalah kualitasnya dengan pendidikan yang di luar negeri. Pembelajaran sejarah sebagai salah satu mata pelajaran dalam kurikulum 2013 mempunyai tantangan untuk melatih peserta didik memiliki kemampuan berpikir HOTS (Higher Order Thinking Skill). Oleh karena itu, perlu dikembangkan instrumen penilaian yang memberikan ruang gerak kepada peserta didik untuk meningkatkan kemampuan berpikir kritis, logis, dan kreatif, sehingga mampu mengantarkan peserta didik mencapai kemampuan yang dituntut oleh kurikulum 2013 yang level kognitifnya berpikir tingkat tinggi. Dalam mencapai hal tersebut, guru seyogyanya harus paham terlebih dahulu cara membuat soal bertipe HOTS. Artikel ini akan membahas suatu teknik dalam menyusun instrumen penilaian soal bertipe HOTS khususnya dalam pembelajaran sejarah.

\section{METODE PENELITIAN}

Jenis penelitian yang dilakukan penulis adalah penelitian kualitatif yang bersifat studi kepustakaan (library research). Studi kepustakaan bermaksud untuk menghimpun informasi yang relevan dengan topik atau masalah yang akan atau sedang diteliti. Salah satu tujuan studi kepustakaan adalah mencari informasi yang relevan dan mengkaji beberapa teori dasar yang relevan dengan masalah yang diteliti. Dalam penelitian ini, penulis mengkaji beberapa teori teknik penyusunan instrumen penelitian HOTS khususnya dalam pembelajaran sejarah. Studi kepustakaan diperoleh data dari buku-buku ilmiah, laporan penelitian, karangan ilmiah, tesis, disertasi, peraturan dan ketetapan, ensiklopedia serta sumber-sumber tertulis lainnya baik elektronik maupun cetak sebagai sumber utama (Muhadjir, 1998: 3). Penelitian dengan jenis tersebut akan memberikan gambaran dan keterangan yang jelas, sistematis, analitis mengenai teknik penyusunan dalam instrumen penilaian HOTS khususnya dalam pembelajaran sejarah.

Dalam penelitian kepustakaan sumber data yang diperoleh ada dua macam yakni: sumber primer dan sumber sekunder. Sumber primer adalah suatu referensi yang dijadikan sebagai sumber utama acuan penelitian. Sumber utama yang digunakan penulis adalah modul penyusunan soal HOTS yang diterbitkan oleh Kementerian Pendidikan dan Kebudayaan (2017) dan jurnal penelitian dari Widana berjudul Higher Order Thinking Skills Assessment (HOTS). Sementara itu sumber sekunder adalah referensi-referensi pendukung dan pelengkap bagi sumber primer. Dalam penelitian ini, penulis menggunakan beberapa penelitian yang relevan dari berbagai jurnal terkait penilaian HOTS sebagai referensi pendukung. Teknik pengumpulan data penelitian berupa data-data kepustakaan yang telah dipilih, dicari, disajikan dan dianalisis berupa teknik penyusunan instrumen penilaian HOTS 
khususnya dalam pembelajaran sejarah. Data yang disajikan adalah data yang berbentuk kata yang memerlukan pengolahan secara ringkas dan sistematis (Muhadjir, 1998: 29). Data yang diperoleh kemudian dianalisis untuk diolah dalam kerangka kerja sederhana (Zed, 2004: 70). Dalam penelitian ini, teknik analisis data berupa analisis isi (content analysis). Analisis isi merupakan analisis ilmiah tentang isi pesan suatu data (Muhadjir, 1998: 49). Tujuan analisis data tersebut adalah untuk menjelaskan suatu data agar lebih mudah dipahami dalam membuat kesimpulan.

\section{HASIL PENELITIAN DAN PEMBAHASAN}

\section{Pengertian HOTS (Higher Order Thinking Skill)}

Menurut Anderson \& Krtahwohl (2011), tingkat kemampuan berpikir dimulai dari (1) mengingat, (2) memahami, (3) mengaplikasikan, (4) menganalisis, (5) mengevaluasi, sampai dengan (6) mencipta. Tingkatan kemampuan berpikir (1), (2), dan (3) dikategorikan sebagai Lower Order Thinking Skills (LOTS) atau kemampuan berpikir tingkat rendah. Sementara tingkatan kemampuan berpikir (4), (5), dan (6) dikategorikan sebagai Higher Order Thinking Skill atau kemampuan berpikir tingkat tinggi. Lower Order Thingking Skills (LOTS) atau kemampuan berpikir tingkat rendah hanya mampu menjawab pertanyaan-pertanyaan faktual yang alternatif jawabannya hanya satu. Umumnya jawaban tersebut berupa sesuatu yang dapat ditemukan langsung di buku atau hapalan, seperti pertanyaan Siapa? Kapan? Dimana? Kemampuan berpikir tingkat rendah merupakan perantara untuk kemampuan berpikir yang lebih tinggi atau yang dikenal dengan HOTS (Higher Order Thinking Skill).

Sutanto \& Retnawati (2016: 190) menyatakan HOTS (Higher Order Thinking Skill) merupakan aspek yang penting untuk dikembangkan dalam pembelajaran. Tujuan pembelajaran mengembangkan HOTS adalah untuk membekali peserta didik dalam memberi alasan (menganalisis) dan membuat keputusan. Pentingnya HOTS dalam pembelajaran juga ditunjukkan oleh hasil penelitian Murray (2011: 210) yang menyebutkan bahwa ketika peserta didik memutuskan menggunakan HOTS, maka peserta didik tersebut harus mampu menciptakan ide-ide baru, membuat prediksi dan memecahkan masalah. Muhadjir (1998: 202) menyimpulkan instrumen penilaian HOTS adalah soal-soal yang menuntut keterampilan berpikir tingkat tinggi. Dalam membentuk kualitas peserta didik yang lebih baik, soal-soal HOTS harus dikembangkan oleh guru. HOTS atau keterampilan berpikir tingkat tinggi dibagi menjadi tiga kelompok, yaitu: (1) pemecahan masalah, (2) membuat keputusan, (3) berpikir kreatif. King (2010: 1) mendefinisikan HOTS sebagai kemampuan berpikir tingkat tinggi yang meliputi, refleksi, metakognitif dan berpikir kreatif. Selain itu, Dhewa Kusuma (2017: 27) memberikan gambaran perbedaan mengenai LOTS dan HOTS yang bisa dilihat pada tabel di bawah ini. 
Tabel 1. Deskripsi dan Kata Kunci dari Revisi Taksonomi Bloom

\begin{tabular}{|c|c|c|}
\hline Kategori & Kata Kunci/Indikator & Keterangan \\
\hline $\begin{array}{l}\text { Mengingat } \\
\text { Bisakah peserta didik } \\
\text { mengingat atau menghafal } \\
\text { informasi yang telah } \\
\text { diperolehnya? }\end{array}$ & $\begin{array}{l}\text { Menyebutkan definisi, meniru } \\
\text { pengucapan, menyatakan } \\
\text { struktur, mengulangi,dan } \\
\text { menyatakan }\end{array}$ & \multirow{3}{*}{$\begin{array}{l}\text { LOTS } \\
\text { (Lower Order } \\
\text { Thinking Skill) }\end{array}$} \\
\hline $\begin{array}{l}\text { Memahami } \\
\text { Bisakah peserta didik } \\
\text { menjelaskan konsep, prinsip, } \\
\text { hukum atau prosedur? }\end{array}$ & $\begin{array}{l}\text { Mengklasifikasikan, } \\
\text { menjelaskan identifikasi, } \\
\text { menjelaskan dengan kalimat } \\
\text { sendiri }\end{array}$ & \\
\hline $\begin{array}{l}\text { Menerapkan } \\
\text { Bisakah peserta didik } \\
\text { menerapkan pemahamannya } \\
\text { dalam situasi baru? }\end{array}$ & $\begin{array}{l}\text { Memilih, mendemonstrasikan, } \\
\text { bertindak, mengilustrasikan, } \\
\text { menafsirkan, membuat sketsa, } \\
\text { memecahkan masalah. }\end{array}$ & \\
\hline $\begin{array}{l}\text { Menganalisis } \\
\text { Bisakah peserta didik } \\
\text { mengklasifikasikan sesuatu } \\
\text { berdasarkan perbedaan dan } \\
\text { persamaannya. }\end{array}$ & $\begin{array}{l}\text { Memeriksa, membandingkan, } \\
\text { membedakan, melakukan } \\
\text { diskriminasi, memisahkan, } \\
\text { melakukan percobaan. }\end{array}$ & \multirow{3}{*}{$\begin{array}{l}\text { HOTS } \\
\text { (Higher Order } \\
\text { Thinking Skill) }\end{array}$} \\
\hline $\begin{array}{l}\text { Mengevaluasi } \\
\text { Apakah peserta didik dapat } \\
\text { menyatakan baik atau buruk } \\
\text { terhadap suatu fenomena atau } \\
\text { objek tertentu? }\end{array}$ & $\begin{array}{l}\text { Memberikan argumentasi, } \\
\text { membela, menyatakan, } \\
\text { memilih, memberikan } \\
\text { dukungan, memberikan } \\
\text { penilaian, melakukan evaluasi }\end{array}$ & \\
\hline $\begin{array}{l}\text { Menciptakan } \\
\text { Bisakah peserta didik membuat } \\
\text { sesuatu atau pendapat? }\end{array}$ & $\begin{array}{l}\text { Merakit, mengubah, } \\
\text { membangun, membuat, } \\
\text { merancang, menetapkan, } \\
\text { merumuskan, menulis. }\end{array}$ & \\
\hline
\end{tabular}

Dari tabel dan penjelasan beberapa ahli di atas, dapat disimpulkan bahwa HOTS lebih menekankan pada kemampuan menganalisis, mengevaluasi, dan mengkreasi. Kemampuan berpikir tingkat tinggi juga merupakan kemampuaan dalam memecahkan masalah serta bisa memberikan solusi secara kreatif. Sekolah Menengah Atas semestinya harus siap dalam mengahadapi tantangan internal dan eksternal. Tantangan eksternal antara lain terkait dengan arus globalisasi dan berbagai isu yang terkait dengan masalah lingkungan hidup, kemajuan teknologi dan informasi, kebangkitan industri kreatif, budaya, dan perkembangan pendidikan di tingkat internasional. Salah satu langkah dalam menghadapi tantangan tersebut adalah dengan melatih peserta didik SMA untuk memiliki kemampuan berpikir tingkat tinggi (HOTS) yang sesuai dengan standar internal kurikulum 2013.

\section{Langkah-Langkah Membuat Instrumen Penilaian HOTS}

Guru sebagai ujung tombak dalam dunia pendidikan harus memperhatikan langkah-langkah dalam membuat penilaian berbentuk HOTS. Langkah-langkah 
tersebut berguna sebagai pedoman dan petunjuk jelas dalam membuat soal berbentuk HOTS. Adapun langkah-langkah dalam membuat penilaian HOTS menurut Widana (2017: 39) adalah sebagai berikut:

1. Menganalisa KD yang bisa diukur dalam penilaian HOTS. Pilihlah KD yang membutuhkan kemampuan untuk menganalisis, mengevaluasi, atau mengkreasikan.

2. Mengembangkan kisi-kisi. Secara umum, materi pengukuran menggambarkan KD yang akan diukur, subjek yang akan diuji, indikator dan level kognitif (pengetahuan). Oleh karena itu, soal harus berisi keterkaitan antara KD, indikator soal, materi, level kognitif dan bentuk soalnya.

Tabel 2. Contoh Susunan Kisi-Kisi Soal

\begin{tabular}{lllllc}
\hline \multicolumn{1}{c}{ KD } & \multicolumn{1}{c}{ Materi } & $\begin{array}{c}\text { Indikator } \\
\text { Soal }\end{array}$ & $\begin{array}{c}\text { Level } \\
\text { Kognitif }\end{array}$ & $\begin{array}{c}\text { Bentuk } \\
\text { Soal }\end{array}$ & No.Soal \\
\hline Menganalisis & Perjuangan & Menganali & C-4 & Pilihan & 1 \\
perjuangan & bangsa: & $\begin{array}{l}\text { sis alasan } \\
\text { Belanda }\end{array}$ & Ganda & \\
bangsa Indonesia & antara & Beland & & \\
dalam upaya & perang dan & ingin & & & \\
mempertahankan & damai & kembali & & & \\
kemerdekaan & & ke & & & \\
dari ancaman & & Indonesia & & & \\
Sekutu dan & & & & & \\
Belanda & & & & & \\
\end{tabular}

Sumber : (Wahidmurni, 2015: 13)

3. Menulis pertanyaan. Pertanyaan yang ditulis harus sesuai dengan kriteria yang ditetapkan dalam materi dan menampilkan masalah aktual. Masalah HOTS biasanya dalam bentuk kasus, sehingga harus dipertimbangkan stimulus yang tepat dan kontekstual.

4. Menentukan kunci jawaban (bentuk pertanyaan pilihan ganda) atau scoring (bentuk deskripsi). Setiap langkah kunci dijawab dengan benar diberi skor 1 atau 0 jika dijawab salah/tidak ada jawaban.

5. Melakukan analisis kualitatif. Analisis kualitatif bertujuan untuk melihat kesesuaian item dengan konvensi penulisan item. Hasil analisis ada tiga jenis, yaitu diterima, diterima dengan perbaikan, atau ditolak. Diterima ketika semua komponen analisis sesuai dengan aturan menulis item. Diterima dengan perbaikan jika ketidak-sesuaian hanya terletak pada aspek konstruksi atau bahasa, sedangkan soal yang dinyatakan ditolak atau dibuang jika ada item yang tidak cocok yang terkandung dalam aspek material. Hanya soal yang diterima dan diperbaiki yang dapat diuji (analisis kuantitatif).

6. Melakukan analisis kuantitatif. Analisis kuantitatif bertujuan untuk menentukan karakteristik termasuk membedakan item, tingkat kesulitan item, fungsi atau tidak adanya hubungan, dan tebakan (bentuk khusus dari pertanyaan pilihan ganda). 
Sementara itu, Kementerian Pendidikan dan Kebudayaan (2017: 21) juga merumuskan langkah-langkah penyusunan soal berbasis HOTS yang tidak jauh berbeda dengan Widana, sebagai pedoman untuk guru. Langkah-langkah tersebut diantaranya:

1. Menganalisis KD yang dapat dibuat soal-soal HOTS. Pemilihan KD tidak boleh sembarangan dan terpaku pada KKO (Kata kerja Operasional), sebab KKO dalam penilaian HOTS hanya sebagai panduan awal yang diperkaya dengan substansi lainnya.

2. Menyusun kisi-kisi soal. Penulisan kisi-kisi bertujuan nntuk memandu guru dalam (1) memilih KD yang dapat dibuat soal HOTS, (2) memilih materi pokok yang terkait dengan KD yang akan di uji, (3) merumuskan indikator soal, dan (4) menentukan level kognitif.

3. Memilih stimulus yang menarik dan konstektual. Stimulus yang menarik umumnya baru, belum pernah dibaca oleh peserta didik. Sementara stimulus kontekstual berarti stimulus yang sesuai dengan kenyataan dalam kehidupan sehari-hari, menarik dan mendorong peserta didik untuk membaca. Dalam konteks ujian sekolah, guru dapat memilih stimulus dari lingkungan sekolah atau daerah setempat.

4. Menulis butir pertanyaan sesuai dengan kisi-kisi soal. Penulisan butir soal HOTS harus sesuai dengan langkah-langkah sebelumnya, yakni disesuaikan dengan KD, materi serta stimulus yang dekat dengan kehidupan peserta didik.

5. Membuat pedoman penskoran (rubrik) atau kunci jawaban. Setiap butir soal HOTS yang ditulis hendaknya dilengkapi dengan pedoman penskoran atau kunci jawaban. Pedoman penskoran dibuat untuk bentuk soal uraian. Sementara kunci jawaban dibuat untuk bentuk soal pilihan ganda, pilihan ganda kompleks (benar/salah, ya/tidak), dan isian singkat.

Berdasarkan beberapa pendapat tersebut terkait langkah-langkah penyusunan soal HOTS dalam pembelajaran sejarah, dapat ditarik suatu kesimpulan bahwa langkah pertama yang harus dilakukan adalah menganalisa KD, guru terlebih dahulu memilih KD mata pelajaran sejarah yang digunakan dalam kurikulum 2013. Setelah itu, analisis mana saja KD yang berada pada level kognitif berdasarkan taksonomi bloom dan sesuai dengan level HOTS. Adapun level kognitif yang dimaksud adalah menganalisis (C4), mengevaluasi (C5), dan mengkreasikan (C6). Langkah kedua adalah mengembangkan kisi-kisi, pada langkah ini soal harus berisi keterkaitan antara KD, indikator soal, materi, level kognitif dan bentuk soalnya.Langkah ketiga, memilih stimulus yang menarik dan konstektual. Dalam konteks ujian sekolah, guru dapat memilih stimulus dari lingkungan sekolah atau daerah setempat. Langkah keempat menulis butir pertanyaan, pada bagian ini pertanyaan yang ditulis harus sesuai dengan kriteria yang ditetapkan dalam materi dan menampilkan masalah aktual. Langkah kelima menentukan kunci jawaban/pedoman penskoran, pada bagian ini pedoman penskoran dibuat untuk bentuk soal uraian. Sementara kunci jawaban dibuat untuk bentuk soal pilihan ganda, pilihan ganda kompleks 
(benar/salah, ya/tidak), dan isian singkat. Langkah keenam melakukan analisis kualitatif, bagian ini bertujuan untuk melihat kesesuaian item dengan konvensi penulisan item. Langkah ketujuh melakukan analisis kuantitatif, bagian ini bertujuan untuk menentukan karakteristik termasuk membedakan item, tingkat kesulitan item, fungsi atau tidak adanya hubungan, dan tebakan (bentuk khusus dari pertanyaan pilihan ganda).

\section{SIMPULAN}

Instrumen penilaian berbasis HOTS lebih menekankan pada kemampuan menganalisis, mengevaluasi, dan mengkreasi. Kemampuan berpikir tingkat tinggi juga merupakan kemampuaan dalam memecahkan masalah serta bisa memberikan solusi secara kreatif. Adapun teknik penyusunan membuat penilaian berbasis HOTS menurut Widana (2017: 39) adalah sebagai berikut: (1) menganalisa KD yang bisa diukur dalam penilaian HOTS, (2) mengembangkan kisi-kisi, (3) menulis pertanyaan, (4) menentukan kunci jawaban, (5) melakukan analisis kualitatif; dan (7) melakukan analisis kuantitatif. Sementara itu, Kementerian Pendidikan dan Kebudayaan (2017: 21) juga merumuskan langkah-langkah penyusunan soal berbasis HOTS sebagai pedoman untuk guru, yaitu: (1) menganalisis KD; (2) pemilihan KD tidak boleh sembarangan dan terpaku pada KKO (Kata kerja Operasional); (3) mengembangkan kisi-kisi soal; (4) penulisan kisi-kisi; (5) memilih stimulus yang menarik dan konstektual; (6) menulis butir pertanyaan sesuai dengan kisi-kisi soal dan harus sesuai dengan langkah-langkah sebelumnya, (7) Membuat pedoman penskoran (rubrik) atau kunci jawaban. Berdasarkan kedua pendapat tersebut, dapat disimpulkan bahwa teknik penyusunan membuat penilaian berbasis HOTS dalam pembelajaran sejarah terdiri dari: (1) menganalisa KD, (2) mengembangkan kisi-kisi, (3) memilih stimulus yang menarik dan konstektual, (4) menulis butir pertanyaan sesuai dengan kisi-kisi soal, (5) menentukan kunci jawaban, (6) melakukan analisis kualitatif, dan (7) melakukan analisis kuantitatif.

\section{DAFTAR PUSTAKA}

Anderson, \& Krtahwohl, D. (2011). A Taxonomy for Learning, Teaching, and Assessing: A Revision of Bloom's Taxonomy. New York: Longman Publishing.

Anggara, T. (2015). Kesulitan-Kesulitan Guru Sejarah dalam Mengembangkan dan Menerapkan Penilaian Pembelajaran Sejarah di SMA Islam I Gamping. Universitas Negeri Yogyakarta. Retrieved from https://eprints.uny.ac.id/23753/

Dhewa Kusuma, M. (2017). The Development of Higher Order Thinking Skill (HOTS) Instrument Assessment in Physics Study. IOSR-JRME (IOSR Journal of Research $\mathcal{E}$ Method in Education), 7(1). Retrieved from https://www.google.com/url?sa= t\&rct=j\&q=\&esrc=s\&source=web\&cd=1\&ved=2ahUKEwjWrbXP1sPmAhXX6X MBHbEBCDMQFjAAegQIBBAC\&url=https\%3A\%2F\%2Fwww.iosrjournals.org 
\%2Fiosr-jrme\%2Fpapers\%2FVol-7\% 2520Issue-1\%2FVersion-5\%2FD0701052632. pdf \&usg=AOvVaw0YbecMlHmoMWxZKy2db_u

Kementerian Pendidikan dan Kebudayaan. (2017). Modul Penyusunan Soal Higher Order Thinking Skill (HOTS). Jakarta: Direktorat Jenderal Pendidikan Dasar dan Menengah Departemen Pendidikan Dan Kebudayaan.

King, A. (2010). Psikologi Umum Sebuah Pandangan Apresiatif. Jakarta: Slemba Humanika.

Kochhar, S. (2008). Pembelajaran Sejarah. (Purwanta dan Yofita Hardiwati, Ed.). Grasindo.

Mainali, B. . (2012). Higher Order Thinking in Education. A Multidisciplinary, 2(1), 510. Retrieved from https://pdfs.semanticscholar.org/e409/15a12d8b8fba 558db8847a0414e44ed322f6.pdf

Mardapi, D. (1999). Estimasi Kesalahan Pengukuran dalam Bidang Pendidikan dan Implikasinya Pada Ujian Nasional. Yogyakarta.

Murray, E. (2011). Implementing Higher Order Thinking in Middle School Mathematics Classrooms. University of Georgia. Retrieved from https://getd.libs.uga.edu/ pdfs/murray_eileen_c_201105_phd.pdf.

Muhadjir, N. (1998). Metodologi Penelitian Kualitatif. Yogyakarta: Rake Sarasin.

Pi'i. (2016). Mengembangkan Pembelajaran dan Penilaian Berpikir Tingkat Tinggi pada Mata Pelajaran Sejarah. Sejarah Dan Budaya, 10(2). Retrieved from https:// www.google.com/url?sa=t\&rct=j\&q=\&esrc=s\&source=web\&cd=1\&cad $=$ rja\&uact $=8 \&$ ved $=2$ ahUKEwiIrfnzz8PmAhVR4jgGHenDDnMQFjAAegQIARA C\&url=http\%3A\%2F\%2Fjournal.um.ac.id\%2Findex.php\%2Fsejarah-dan-budaya \%2Farticle\%2Fdownload\%2F7676\%2F3499\&usg=AOvVaw3FxOO-49d5P5cq

Sutanto, \& Retnawati. (2016). Perangkat Pembelajaran Matematika Bercirikan PBL untuk Mengembangkan HOST Siswa SMA. Riset Pendidikan Dan Matematika, $3(2)$.

Umi, \& Eka. (2015). Pengembangan Insrumen Penilaian HOTS Berbasis Kurikulum 2013 Terhadap Sikap Disiplin. Penelitian Dan Pembelajaran, 1(1). Retrieved from http://jurnal.untirta.ac.id/index.php/JPPI/article/view/330

Wahidmurni. (2015). Pengembangan Penilaian untuk Mengukur Kemampuan Berpikir Tingkat Tinggi (Higher Order Thinking Skills/Hots).

Widana, I. W. (2017). Higher Order Thinking Skills Assessment (Hots). Indonesian Student Assessment and Evaluation, 3(1). Retrieved from http://journal.unj.ac.id/ unj/index.php/jisae/article/view/4859

Zed, M. (2004). Metode Penelitian Kepustakaan. Jakarta: Yayasan Obor Indonesia.

Zulkarnain. (2017). Kebijakan Kurikulum Sejarah di Sekolah Menegah Atas. Universitas Negeri Yogyakarta. 